\title{
Pitfalls to the Current Expansion
}

\author{
NEIL A. STEVENS
}

$\mathrm{T}$ HE economic expansion following the 1973-75 recession has entered into its fourth year. ${ }^{1}$ Of the five previous economic expansions dated by the National Bureau of Economic Research, all but one lasted at least three years, but only one of these expansions was sustained beyond the four-year mark. The longer-run experience of U.S. business fluctuations since the end of the Civil War indicates that only three of the previous 25 business expansions lasted 16 quarters or longer, and each of these was associated with unusual circumstances such as war. As the current recovery completes its thirteenth quarter of expansion, this historical perspective brings into question whether forces are now developing which may soon end the current business expansion.

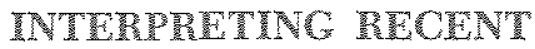 DCONOMO INDICATORS}

\section{Economy Shows Strengh ...}

Indicators of business activity show the economy has continued to expand in recent months. From February to June, industrial production grew at an 11 percent annual rate, personal income increased at a 14 percent rate, and total employment rose at a 6 percent rate.

These rapid gains, however, followed temporary losses in economic activity in early 1978, which largely reflected the effects of the abnormally severe winter weather and lengthy coal miners' strike. The strength of recent economic activity, therefore, is

For a comparison of the first three years of the current expansion with other postwar expansions, see Jear Lovati, "A Pe:spective on the Economy: Three Years of Expansion," this Review (May 19"8), pp. 2-7.

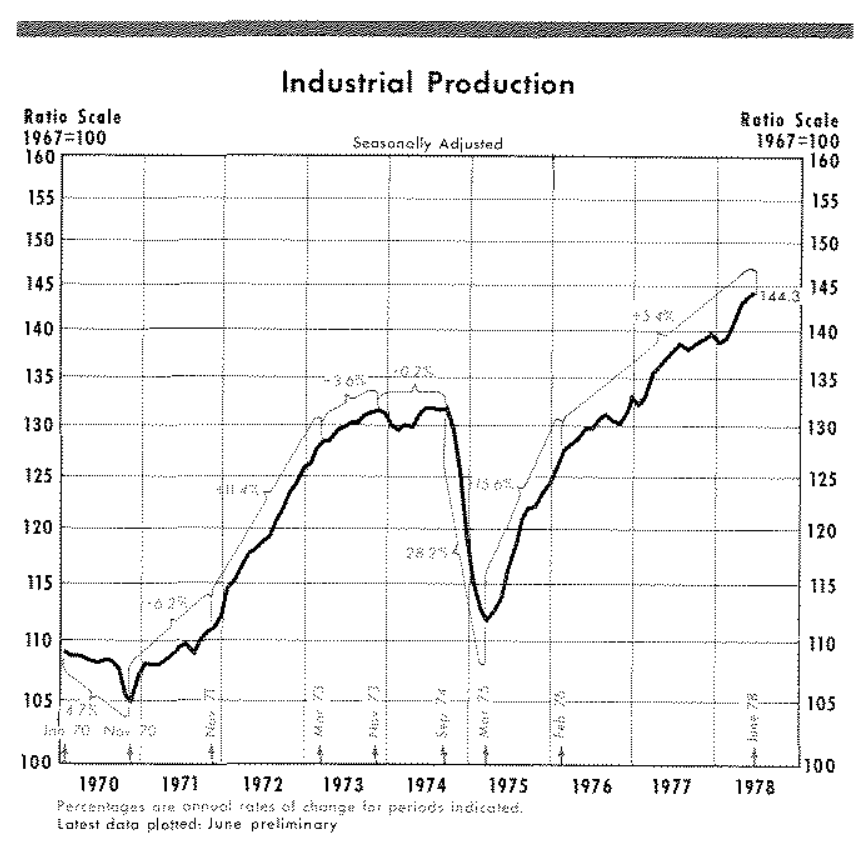

overstated in recent data since part of the increase represents a catch-up from the winter months. Most of this catch-up appears to have been registered in March and April, while in May and June most economic indicators continued to advance, but at substantially reduced rates from those in the preceding two months. For example, industrial production registered a 5.6 percent rate of increase in May and June, down from an unsustainable 17 percent rate of increase in March and April.

The growth of the economy over the winter slump and subsequent rebound period has been, on balance, similar to that registered in the preceding year. In the six-month period ending in June, industrial produc- 


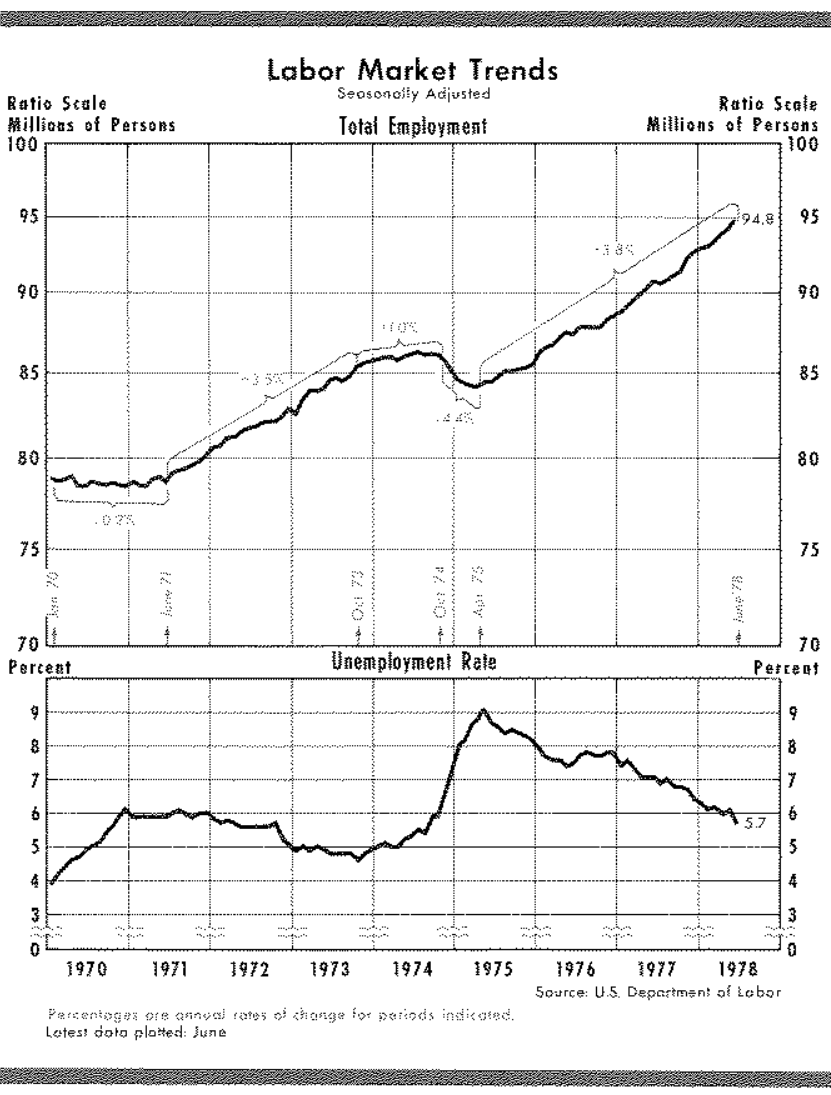

tion grew at a 6.7 percent annual rate, total employment advanced at a 4.8 percent rate, and personal income rose at an 11 percent rate, all of which are quite similar to, or somewhat above, the gains registered by the respective measures in the previous year.

\section{... But Prices Accelerate}

The most unfavorable economic development in recent months has been the sharp increases in prices. For example, producer prices for all commodities (formerly wholesale prices) rose at over an 11 percent annual rate in the first six months of 1978 , much faster than the 5.9 percent increase recorded in 1977 . But these recent increases also overstate the underlying inflation rate. Both agricultural and industrial commodity prices have increased shaply so far this year, although the acceleration has been most pronounced for agricultural prices. In some respects, these sharp increases are not unlike those registered in the early months of last year. For example, in the first six months of 1977 , prices of farm products and processed foods and feeds rose at almost a 22 percent amual rate, but then registered a decline in the summer months and ended the year only 3 percent above a year earlier. Industrial commodity prices also increased sharply in the first six months

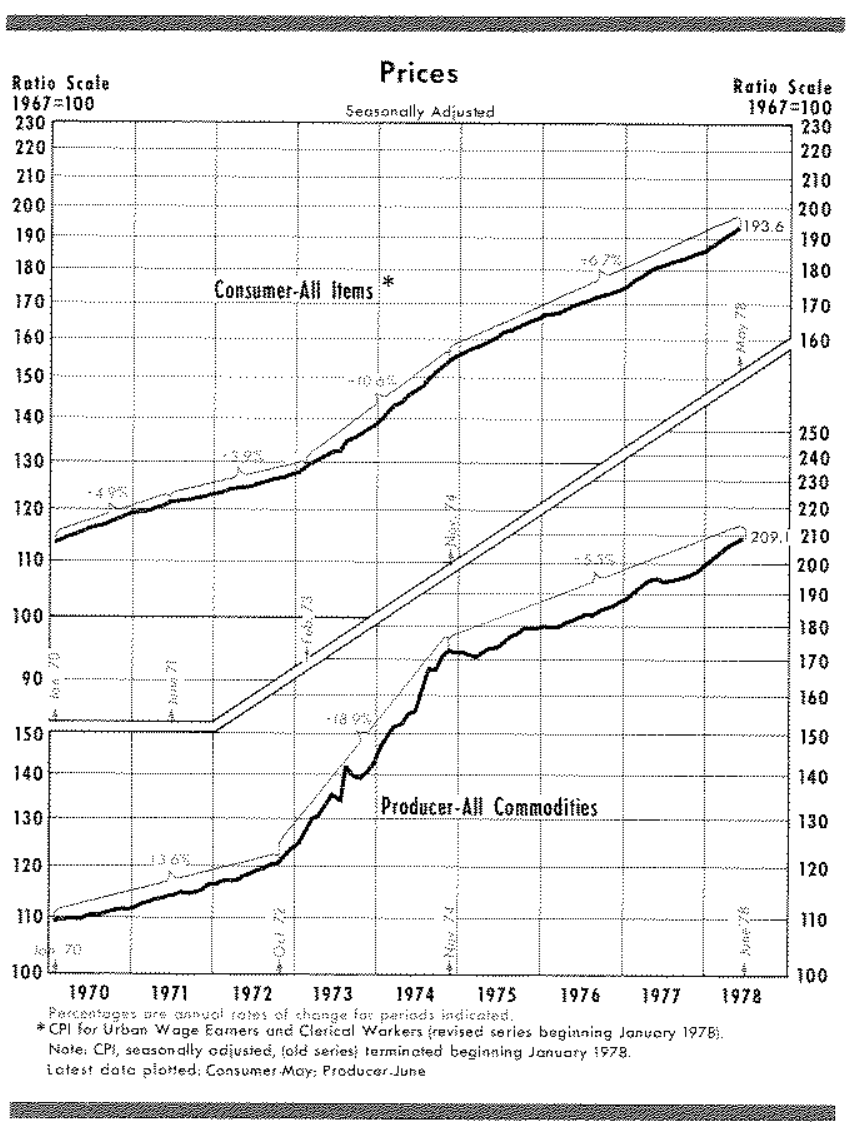

of 1977 , registering a 7.6 percent rate of increase, similar to this year's experience; over the second half of 1977, however, these prices advanced at the more moderate rate of 5.9 percent.

Like last year, unusually bad weather hampered the production of some fruits and vegetables early this year. Some moderation in the rate of advance in food commodity prices can be expected as these supplies are normalized, but changes in the supply of and demand for agricultural products have occurred which are not likely to be quickly reversed. In contrast to last year, prospects for the production of some major crops this season are down, partly based on Government actions to restrict acreages planted. In addition, demand for U.S. agricultural products is stronger this year, based in pat on unexpected strength in foreign demand. In addition, some of the sharpest food price increases have been among meats, where the supply response is limited by the biological nature of the production process. Thus, sharp declines in agricultural commodity prices, such as occurred last summer, are not as likely this summer.

At the retail level, consumer prices have increased at about a 10 percent annual rate in the first five months of 1978 , compared with an increase of 6.8 
percent in all of 1977 . Food prices have been one of the biggest gainers this year, registering an 18.5 percent rate of increase in the first five months of the year, while consumer items less food rose at about an 8 percent rate. Increases in food prices are expected to moderate in the second half of the year as the U.S. Department of Agriculture expects a rise of 8 to 10 percent in food prices for all of 1978. Such an increase in food prices, however, does suggest that consumer expenditures for food will accelerate from the rate of increase last year. Thus, to some extent, expenditures in other sectors may be slowed somewhat, lessening demand and price pressures in those sectors of the economy.

\section{SHOCKS AND BUSTNESS RLUCTUATIONS}

Fluctuations in economic activity have been a persistent feature of our economic system. Theories abound as to causes and explanations for such fluctuations. Presumably the economy could achieve a fairly stable growth pattern if it were not buffeted by shocks which move the economy off its long-run path. These shocks include such events as unusual weather patterns, wars, changes in technology, the exercise of monopoly power, and overall government policies, including monetary and fiscal. If such shocks lead to fluctuations in economic activity, then an investigation of some of these forces will provide some basis for deciding how endangered the expansion is at this time.

\section{Monetary Policy Actions}

Monetary actions, as shown by numerous studies, can have substantial effects on economic activity. ${ }^{2}$ One method of gauging the effects of monetary actions on the economy is to examine movements in monetary aggregates, such as the money stock, while another method is examining interest rate movements.

Moneiary Aggregates - Movements in the rate of inflation have been associ- ated with movements in the trend growth of the money stock. In addition, recessions have usually been preceded by a period of marked decline in the rate of money growth below the prevailing trend rate (see accompanying chart).

Money stock (M1) growth from early 1973 through the third quarter of 1976 was generally below its prevailing trend rate. This extended period of belowtrend growth caused the long-run growth of money, which had been generally advancing for about a decade, to level off and to show a slight decline. This downturn in long-run money growth indicated some downward pressure was being applied to the rate of inflation.

Subsequently, growth of the money stock accelerated, and from the third quarter of 1976 to the second quarter of 1978, monetary expansion proceeded at a 7.8 percent rate. More recently, some slowing in the growth of the money stock occurred in the first quarter of this year, but a sharp resurgence of monetary growth in the second quarter offset the first quarter's slowdown. On balance, growth of Ml from the fourth quarter of 1977 to the second quarter of 1978 was recorded at a 7.8 percent annual rate, about the same as in the previous two quarters. Over the past four



2For example, see Leonall $C$. Andersen and Jerry $L_{\text {. Jordan, }}$ portance in Economic Stabilization," this Review (November 1968), pp. 11-24, and Milton Friedman and Anna Schwartz, "Money and Business Cycles," Review of Economics and Statistics, Supplement (February 1963), pp, 32-64.

quarters, M1 grew 7.9 percent, faster than the 6.6 percent rate of increase in the previous four quarters. These recent rates of increase are above the long-run growth of money of the previous five years 
and, if sustained, will again cause the trend growth of $\mathrm{M} 1$ to rise.

Interest Rates - Some analysts judge the stance of monetary policy by examining movements in market interest rates rather than monetary aggregates. Rising interest rates, for example, are interpreted as restricting economic growth, whereas falling or stable interest rates are said to promote faster economic growth by encouraging investment and consumption expenditures.

Interest rates among all maturities have risen substantially in recent months. For example, the Federal funds rate stood at about 7.6 percent in June, up from 6.75 percent in March. The four- to six-month prime commercial paper rate rose from about 6.8 percent in March to approximately 7.63 percent in June, and the rate charged to prime business customers by commercial banks rose from the 8 percent rate prevailing in the first four months of the year to 9 percent in late June. Long-term interest rates have also moved up since last fall. Yields on the highest-grade corporate bonds remained relatively stable at around 8 percent from May through September last year, but they have trended upward since then, reaching 8.77 percent in June.

Market interest rates are the price which equates the demand for and supply of credit. Interpreting move-

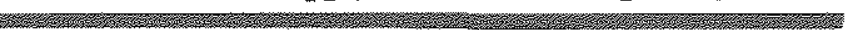

\section{Selected Interest Rates}

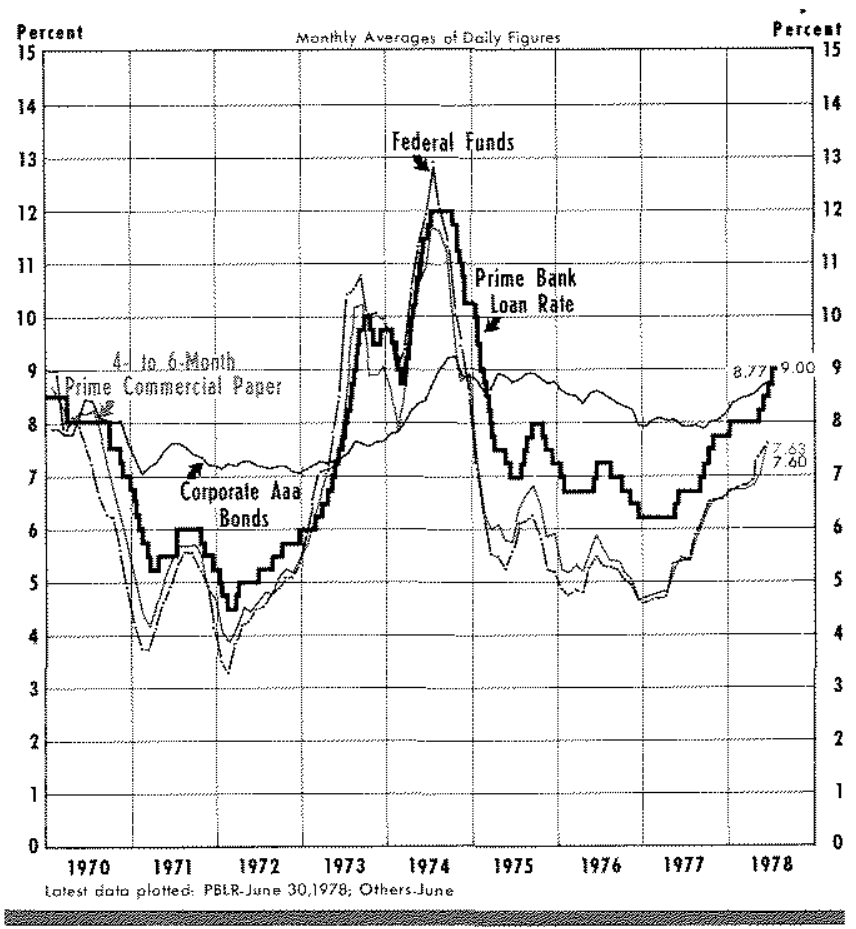

ments in interest rates with respect to the stance of monetary policy is complicated by the fact that interest rate movements can reflect the effects of changes in current monetary actions on the supply of credit or the lagged effects of past monetary actions on the demand for credit.

The recent surge in interest rates appears consistent with the view that the rising interest rates reflect increasing credit demand rather than a constriction of the supply of credit. The fact that loan volume has expanded more rapidly in recent months tends to indicate that the demand for credit has been shifting outward, raising both the price of credit and the volume outstanding. For example, from March to June, business loans increased at a 24 percent annual rate and total bank loans advanced at an 18 percent rate, compared with increases of about 15 percent in the previous year.

Further evidence that monetary actions have not acted to restrict the supply of credit is given by the continued rapid advances in the underlying aggregates such as Federal Reserve credit and the mone-

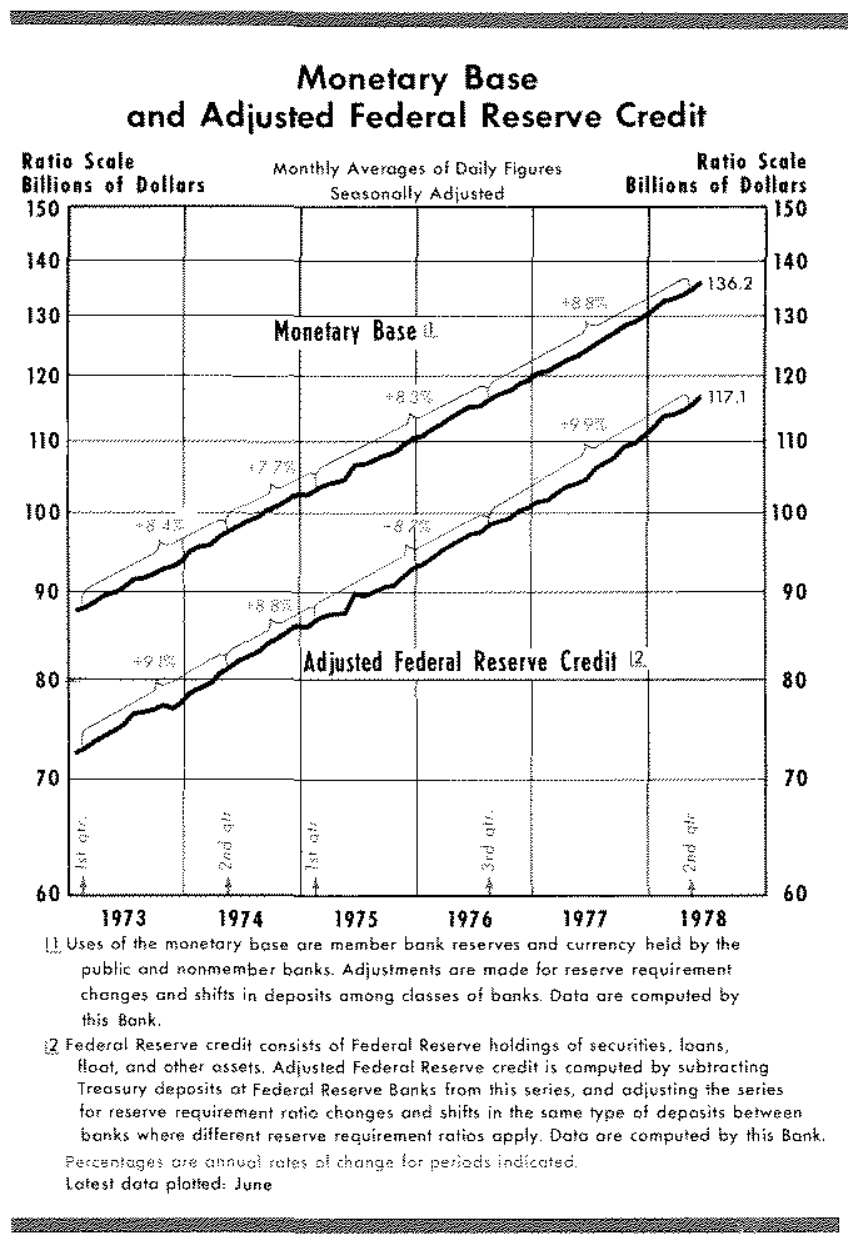


tary base. These aggregates provide the base on which expansion of money and bank credit occurs. The monetary base has expanded at about a 9 percent annual rate in the past two quarters, the same as in the previous year.

\section{Disintemediation}

Given Governmental restrictions on the rates which financial intermediaries are allowed to pay on deposits, rising interest rates have presented another potential shock to the economy. When market interest rates rise above Govemment regulated interest rate ceilings on deposits at financial intermediaries, such as commercial banks and sayings and loan associations, funds are withdrawn from these financial institutions and placed in other market instruments which offer a more attractive yield. This rechanneling of funds, called disintermediation, may favor some borrowers over others.

The rising interest rates over the past year, particularly the increases in recent months, have brought market rates into serious competition for funds at financial intermediaries. The rate of growth of deposits at nonbank thrift institutions, for example, has slowed markedly in recent months, registering an 8 percent rate of increase in the three months ending in June, compared with almost a 13 percent rate of in crease in the previous twelve months. In addition, net time deposits at all commercial banks have increased at an 8 percent rate in the past three months, somewhat below the 9.3 percent rate of increase in the previous year.

Thus, while evidence exists that financial intermediaries are beginning to lose funds to higher-yielding investment alternatives, there are reasons to believe that the disruptive effects on the economy may be minor. Even on previous occasions when disintermediation occurred, there was little evidence that total credit flows were affected; rather, the distribution of credit among sectors was changed. The housing industry has generally been the most affected sector of the economy since it is heavily dependent on credit from the affected financial intermediaries.

Largely because of the previous periods of disintermediation, a number of institutional arrangements have been made to circumvent problems posed by disintermediation. A number of Federal or Federallysponsored agencies, including the Federal National Mortgage Association and Government National Mortgage Association, help transfer funds from the open market into the home mortgage market. In addition, new credit instruments, such as the mortgage-backed security, allow savings and loan associations to tap credit markets for long-term funds. Also, savings and loan associations can borrow from Federal Home Loan Banks which, in turn, draw funds from the open market by selling bonds. Commercial banks can obtain funds in the open market by selling CDs. Recently, thrift institutions, such as commercial banks and savings and loan associations, have been allowed to offer time deposits of six-month maturity with yields pegged to Treasury bill rates, and an eightyear certificate with a yield of 7.75 percent at commercial banks and 8 percent at savings and loan associations.

\section{Fiscal Policy Actions}

Fiscal actions can have short-run effects on total spending and output. Over longer periods of time, however, Government spending financed by borrow. ing tends to displace private spending for goods and services, and thus has little lasting effect on economic activity. During this expansion, Government deficits have been at unprecedented levels for a peacetime period. The severity of the $1973-75$ recession plus continued rapid Government spending pushed the national income accounts budget deficit to $\$ 70$ billion for calendar year 1975 . With increasing tax revenues and lessened expenditures for unemployment

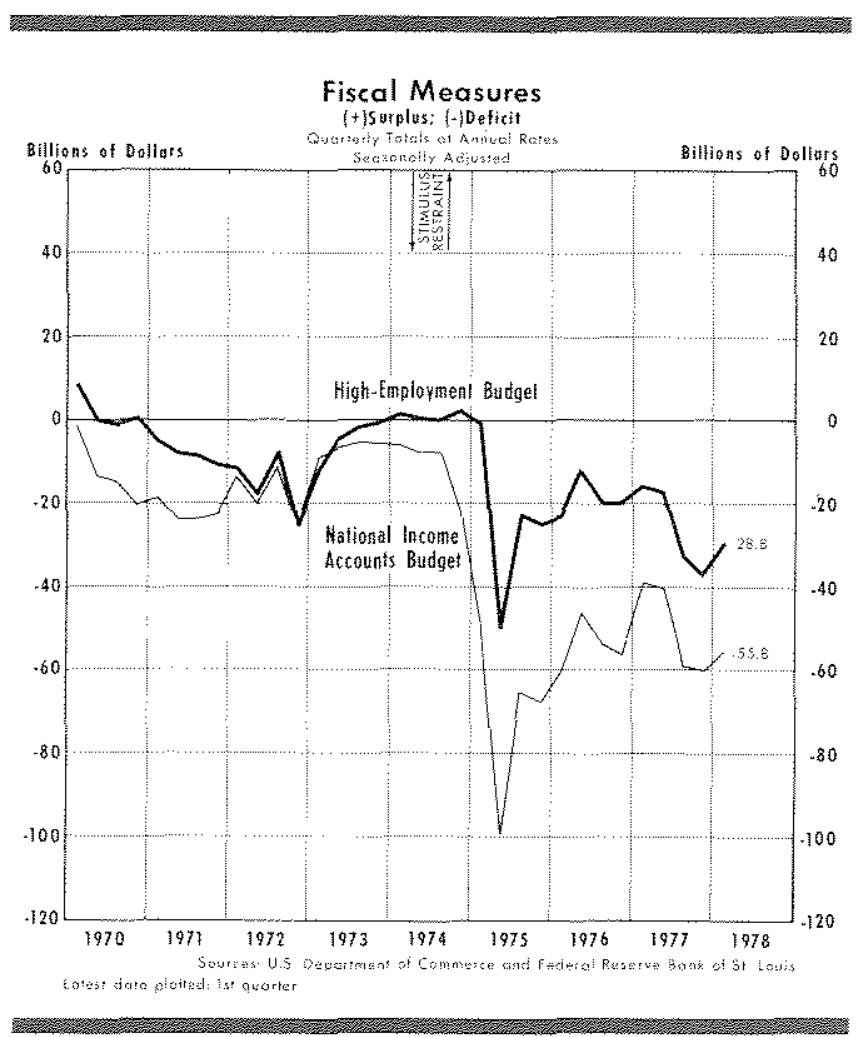


insurance and other recession-induced expenditures, the budget deficit declined to about $\$ 50$ billion in 1977 , still at a very high level for this stage of the expansion.

The high-employment budget, a budget measure adjusted to remove some of the effects on revenues and expenditures of variations in economic activity, was in deficit about $\$ 25$ billion in 1977. The rate of Govermment spending accelerated sharply in the second half of 1977 , however, so that the high-employment deficit of about $\$ 16$ billion in the first half of 1977 increased to $\$ 34$ billion in the second half of 1977 . Based on the President's original tax cut proposal and the March expenditure revisions, the high-employment budget was estimated to remain in deficit at around $\$ 27$ billion in both 1978 and 1979 . These estimated deficits, however, have been revised downward somewhat, reflecting the July expenditure revisions and the reduction in the President's tax cut proposal from $\$ 25$ to $\$ 20$ billion. Nevertheless, the prospect remains for relatively large budget deficits in 1978 and 1979 , making it difficult to interpret the stance of fiscal policy as highly restrictive.

\section{Other Shocks}

Numerous shocks other than those introduced by monetary and fiscal policies affect economic activity. For example, as we saw earlier, the unfavorable weather and prolonged coal miners' strike last winter had visible effects on economic activity in the first quarter as economic output was reduced to a standstill and prices accelerated. Perhaps the greatest longrun danger from such events is the uncertainty created about the future course of the economy. Such uncertainty can serve to generate perverse expectations, which could result, for example, in significant inventory adjustments. Recent legislative acts, such as increased minimum wages, social security taxes, and farm subsidies, will have adverse effects on economic activity, but such effects are unlikely to be large enough to threaten the current expansion.

Capacity Consinaints - A major shock was introduced into the economy in 1973 and 1974 as a result of the sharp rise in oil prices which caused a reduction in potential output of the economy. While engineering capacity presumably remained intact, economic capacity was reduced. This decline, it is argued, was

Robert H. Rasche and John A. Taton, "The Effects of the New Energy Regime on Economic Capacity, Production, and Prices," this Review (May 1977), pp. 2-12; and "Energy Resources and Potential GNP," this Retiew (June 1977), pp. $10-24$. permanent, lowering potential output 4 to 5 percent. As of the first quarter of this year, actual output was only about two percent below this measure of economic capacity.

Knowledge about the degree of excess resources in the economy is an important ingredient for the active pursuit of stabilization policies. As full employment of resources is reached, the growth of output becomes dependent on fundamental growth factors such as changes in technology and growth in the labor force. Attempts via stabilization policies to stimulate demand and production to levels which cannot be sustained over the long run will exacerbate inflation and, eventually, may lead to corrective actions and a recession.

\section{POLICV CWOICES AND THE OUTLOOK}

Even though the expansion is beginning to reach "old age" by historical standards, the stimulative monetary and fiscal policies in recent quarters, such as the nearly 8 percent rate of increase of M1 in the past year, indicate a continued rapid increase of total spending through the remainder of this year. As a result, further increases in output and employment are likely in the second half of 1978, although output growth probably will be below that registered over the past three years. Since some excess capacity still exists, however, output growth can advance in the second half at or somewhat above the longum growth rate.

The course of the economy in 1979 and beyond depends heavily on policy actions and other shocks which may occur in the future. An end to the current expansion and the development of another recession could develop in a number of ways. Barring unforeseen shocks, such as the sharp rise in oil prices which occurred in 1973 and 1974, historical experience indicates that sharp changes in monetary and fiscal policies, such as a marked slowing in the rate of monetary growth below the prevailing trend, often result in shocks to economic activity.

Rapid monetary growth over recent quarters has apparently led to some upward revisions in inflation expectations, as noted in revisions of inflation in most cconomic forecasts and as implicitly observed in rising long-term interest rates. Should monetary growth be reduced substantially in the second half of 1978 in order to reverse these inflation expectations, the immediate effect of this monetary slowing is likely to be a slowdown in output growth and, depending on the length and severity of the monetary slowdown, a recession could develop. Reducing inflation expecta- 
tions is a longer-term process, however, entailing an extended period of slower monetary growth.

Alternatively, monetary growth at the upper end of current Ml targets of 4 to 6.5 percent would appear consistent with stabilizing inflation expectations without incurring sizable short-run costs of reduced output and higher unemployment. On the other hand, growth of the money stock at rates similar to or even. above the 8 percent increase which has occurred in the past year would work to boost output and employment somewhat further. While output growth could continue strong for a time, a worsening of inflation is a notable danger to such a course of action.
In summation, for the near term continued economic expansion is likely, but the policy choices which avoid temporary losses in output and/or accelerating inflation are few. The acceleration of monetary growth in the past several quarters has reduced the prospects for simultaneously achieving reduced inflation and continuing output growth. For the near term stabilization of inflation expectations appears to be the only alternative for avoiding a sizable reduction in output growth without putting further upward pressures on prices. Eventually, however, if the rate of inflation is to be reduced, progress toward lowering the trend growth of the money stock must be achieved.

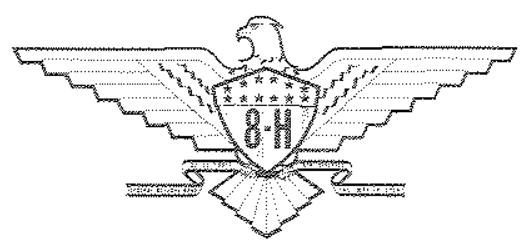

